\title{
PENGARUH TINGKAT PENDIDIKAN TERHADAP KUALITAS KERJA KARYAWAN PADA BANK PERKREDITAN RAKYAT "POLATAMA KUSUMA" KECAMATAN JIWAN KABUPATEN MADIUN
}

\author{
Ekik Mayundarwati \\ Mahasiswa Prodi Pendidikan Ekonomi FPIPS IKIP PGRI Madiun
}

\begin{abstract}
This study aims to determine the level of employee education BPR POLATAMA KUSUMA Madiun, to determine the quality of employees BPR POLATAMA KUSUMA Madiun, and to determine how much influence the level of education of the employees' quality of rural banks "POLATAMA KUSUMA" Madiun. Determination of the sample in this study using a sample that is saturated all employees Rural Bank Polatama Kusuma Madiun totaling 50 employees. Data collection using questionnaires and documentation. In analyzing the data in this study using a linearity test and simple linear regression analysis the $t$ test. The level of education has an average value of 18.60 with a maximum value of 24 , the minimum value of 14 , a standard deviation of 2.523 , median and mode 18.50 by 18 . From the description of the variables is known that the level of education of respondents tended to agree on the level of education is used managers (average 18.60), Quality employees have an average value of 53.64 with a maximum value of 75 , the minimum value of 37, a standard deviation of 9.752, 55.00 median and mode of 60 . From the description of the variable quality of employee respondents tended to have known that the quality of work (average 53.64). Linearity test results note that the value of 0.937 $\geq F_{\text {hitung }} F_{\text {tabel }}$ at 4.03 and Sig linearity of $0.000<0.05$ mean education level has an influence on the quality of employees' BPR POLATAMA KUSUMA Madiun. Results of simple linear regression analysis obtained by the equation $\mathrm{Y}=43.696+0.535 \mathrm{X}$ mean when Level up 1\% Quality Education employees will also rise by $0.535 \%$, while other factors being equal. While the results of the calculation of the t test using SPSS for Windows 16.0 tcount obtained for $0.968>1.677$ for mean Ha ttabel accepted and $\mathrm{H} 0$ is rejected it means there is the influence of the educational level of the employees' quality of BPR POLATAMA KUSUMA Madiun.
\end{abstract}

Keywords : Education Level, Quality Employee

\section{PENDAHULUAN}

Mangkunegara (dalam Tutik Hartini, 2003:50) Tingkat pendidikan merupakan suatu proses jangka panjang yang menggunakan prosedur sistematis dan terorganisir, yang mana tenaga kerja manajerial mempelajari pengetahuan konseptual dan teoritis untuk tujuan-tujuan umum. Hariandja (dalam Tutik
Hartini, 2002: 169) menyatakan bahwa "tingkat pendidikan seorang karyawan dapat meningkatkan daya saing perusahaan dan memperbaiki kinerja perusahaan”.

Semakin lama tingkat persaingan antar pegawai semakin ketat, maka dibutuhkanlah tingkat pendidikan yang lebih mumpuni, yang lebih mampu bersaing untuk memasuki dunia 
keorganisasian dengan lebih baik. Dengan bertambahnya pengalaman seorang karyawan dalam dunia kerja, maka akan bertambah pula pengetahuan, ketrampilan, kecakapan dan kecekatan dalam pengabdian kerjanya di perusahaan. Dengan demikan semakin banyak pengalaman kerja seseorang atau semakin lamanya waktu orang tersebut untuk masa bekerja akan dapat meningkatkan kemampuan kerja sama atau dengan kata lain akan mempengaruhi peningkatan orang yang bersangkutan tersebut. Tentu saja pengalaman memang penting, namun akan lebih optimal jika diimbangi dengan tingkat pengetahuan yang terus diperbarui.

Bilamana perusahaan menginginkan untuk membentuk seorang karyawan agar perusahaan semakin mengikuti perkembangan zaman, maka yang dibutuhkan adalah tingkat pendidikan karyawan yang dibutuhkan oleh perusahaan.Dalam pendidikan terdapat proses yang terus menerus berjalan dan bukan sesaat saja. Namun pendidikan juga bisa disebut sebagai usaha untuk meningkatkan pengetahuan umum seseorang termasuk di dalamnya penguasaan teori untuk memutuskan persoalan-persoalan yang menyangkut kegiatan pencapaian tujuan perusahaan.

Andre E. Sikula (2003:50) tingkat pendidikan seorang karyawan dapat menceminkan kemampuan intelektual dan jenis keterampilan yang dimiliki oleh karyawan tersebut. Memang sudah menjadi kebiasaan dan hal yang umum bahwa jenis-jenis dan tingkat pendidikan seorang karyawan yang biasa digunakan untuk mengukur dan menilai kemampuan seorang karyawan. Mungkin juga masih ada dan banyak hal lain yang mempengaruhi kemampuan seorang karyawan selain tingkat pendidikan artinya tidak mustahil seseorang yang sesungguhnya memiliki tingkat kemampuan intelektual yang cukup tinggi tidak mengecap pendidikan yang tinggi.

Kualitas kerja sebagai teknik manajemen yang mencakup gugus kendali mutu, perkayaan pekerjaaan, suatu pendekatan untuk bernegosiasi dengan serikat pekerja, upaya manajemen untuk memelihara kebugaran mental para karyawan, hubungan industrial yang serasi, manajemen yang partisipatif dan salah satu bentuk intervensi dalam pengembangan organisasional. Dimensi di dalam kualitas kerja yang diharapkan dapat meningkatkan kualitas sumber daya manusia merupakan partisipasi dalam pemecahan masalah, sistem imbalan yang inovatif, perbaikan lingkungan kerja dan restrukturisasi kerja.

Kualitas kerja merupakan masalah utama yang patut mendapat perhatian organisasi, hal ini merujuk pada pemikiran bahwa kualitas kerja dipandang mampu untuk meningkatkan peran serta dan sumbangan para anggota atau karyawan terhadap organisasi. Adanya kualitas kerja juga menumbuhkan keinginan para karyawan untuk tetap tinggal dalam organisasi.

Menurut Flipo (dalam Juwita Sari, 1995:28) berpendapat tentang kualitas kerja sebagai berikut "meskipun setiap organisasi berbeda pandangan tentang standart kualitas kerja pegawai, tetapi pada intinya efektifitas dan efisiensi menjadi ukuran yang umum”.

Menurut Dorothea Wahyu Ariani (2003:9) menyebutkan "Kualitas kerja merupakan bagian dari semua fungsi usaha yang lain (pemasaran, sumber daya manusia, keuangan dan lain - lain”.

Kualitas kerja mengacu pada kualitas sumber daya manusia Matutina (dalam Skripsi Juwita Sari, 2001:205), Kualitas sumber daya manusia mengacu pada :

1. Pengetahuan (Knowledge) yaitu kemampuan yang dimiliki karyawan yang lebih berorientasi pada intelejensi dan daya fikir serta penguasaan ilmu yang luas yang dimiliki karyawan.

2. Ketrampilan (Skill), kemampuan dan penguasaan teknis operasional di bidang tertentu yang dimiliki karyawan.

3. Abilities yaitu kemampuan yang terbentuk dari sejumlah kompetensi yang dimiliki seorang karyawan yang mencakup loyalitas, kedisiplinan, kerjasama, dan tanggung jawab.

kualitas kerja karyawan sebagai suatu hasil yang dapat diukur dengan efektifitas dan 
efisiensi sesuatu pekerjaan yang dilakukan oleh sumber daya manusia atau sumber daya lainnya dalam pencapaian atau sasaran perusahaan dengan baik dan berdaya guna.

Adanya kualitas sumber daya manusia yang handal maka kualitas kerja karyawan akan tinggi dapat berpengaruh mencapai tujuan perusahaan. Perusahaan yang mempunyai karyawan dengan kualitas kerja dan berdaya guna tinggi akan mendorong aktivitas operasional perusahaan sehingga dapat mencapai tujuan dan sasaran yang telah yang telah ditetapkan perusahaan.

Dengan demikian perlu untuk diperhatikan latar belakang tingkat pendidikannya karena tingkat pendidikan yang dimiliki seseorang akan mempengaruhi pola pikir, sikap dan tingkah lakunya dan diyakini bahwa karyawan yang berpendidikan tinggi lebih tinggi pula kualitasnya.

Dengan demikian jelaslah bahwa tingkat pendidikan mempunyai peranan penting bagi suatu organisasi karena dapat mempengaruhi kualitas kerja karyawan.

\section{METODE PENELITIAN}

Penelitian ini mengambil lokasi di BPR POLATAMA KUSUMA dengan alamat jln.Raya Solo No.33 Kecamatan Jiwan Kabupaten Madiun. Waktu yang diperlukan dalam penelitian ini yaitu selama 4 bulan dari bulan Februari 2012 sampai dengan bulan Mei 2012.

Populasi dalam penelitian ini adalah seluruh karyawan pada BPR POLATAMA KUSUMA Madiun yang berjumlah 50 karyawan. Sampel dalam penelitian ini adalah seluruh karyawan pada BPR POLATAMA KUSUMA Madiun sebanyak 50 karyawan yang terdiri dari karyawan 37 orang dan karyawatinya 13 orang. Teknik pengambilan sampel dalam penelitian ini menggunakan teknik sampel jenuh. Menurut Gabriel Amin Silalahi (2003: 76) "sampel jenuh adalah teknik penentuan sampel bila semua anggota populasi digunakan sebagai sampel”.

Dalam penelitian ini teknik pengumpulan data dilakukan melalui angket / kuesioner. Kuesioner dalam penelitian ini untuk mem- berikan jumlah pertanyaan tertulis kepada karyawan pada BPR POLATAMA Madiun mengenai indikator variabel bebas (X) tingkat pendidikan yang digunakan yaitu 1 . jenjang pendidikan ada 2 butir pertanyaan, 2. kesesuaian jurusan 3 butir pertanyaan. Jadi untuk variabel bebas tingkat pendidikan ada 5 butir pertanyaan. Indikator variabel terikat (Y) kualitas kerja karyawan yang digunakan yaitu 1. ketepatan ada 3 butir pertanyaan, 2. kelengkapan ada 3 butir pertanyaan, 3. ketelitian ada 3 butir pertanyaan, 4 . ketrampilan ada 3 butir pertanyaan, dan 5 . pengetahuan ada 3 butir pertanyaan. Jadi untuk variabel terikat kualitas kerja karyawan ada 15 butir pertanyaan. Dalam penelitian ini peneliti menggunakan angket langsung dan tertutup, dimana daftar pertanyaan ditanggapi langsung oleh responden sendiri dengan memilih jawaban yang sudah tersedia. Langkah berikutnya adalah dengan menggunakan dokumentasi. Dokumentasi dalam penelitian ini yaitu dilakukan dengan melampirkan surat ijin perusahaan.

Intstrumen untuk penelitian ini menggunakan angket dengan skala likert. Dalam penelitian ini skala likert digunakan agar mempermudah responden dalam menjawab pertanyaan kemudian responden menjawab pertanyaan sesuai dengan kode yang ada dalam kuesioner.

Hasil pengujian untuk kuesioner tingkat pendidikan setelah diuji dengan SPSS dapat dikatakan bahwa semua item dalam angket tingkat pendidikan adalah valid. Hal ini dapat diketahui dari nilai $\mathrm{r}_{\mathrm{xy}}$ secara keseluruhan hasilnya valid, semua nilai $r_{x y}$ lebih besar $r_{\text {tabel }}\left(r_{x y}\right.$ $\geq r_{\text {tabel }}$ ). Dari hasil tersebut dapat disimpulkan bahwa semua soal yang ada dalam angket tingkat pendidikan dapat digunakan dalam penelitian. Hasil uji validitas kualitas kerja karyawan Perhitungan untuk uji validitas kuesioner kualitas kerja, setelah diuji dengan SPSS dapat dikatakan bahwa semua item dalam angket kualitas kerja karyawan adalah valid. Hal ini dapat diketahui dari nilai $r_{x y}$ secara keseluruhan hasilnya valid, semua nilai $r_{x y}$ lebih besar $r_{\text {tabel }}\left(r_{x y} \geq r_{\text {tabel }}\right)$. Dari hasil tersebut da- 
pat dikatakan bahwa semua soal yang ada dalam angket kualitas kerja dapat digunakan dalam penelitian.

Hasil uji reliabilitas terhadap angket Tingkat Pendidikan dan kualitas kerja karyawan diperoleh nilai Cronbach's Alpha masing-masing sebesar 0,873 dan 0,827 karena nilai Cronbach's Alpha lebih dari 0,7 dapat disimpulkan bahwa data yang dikumpulkan melalui angket tingkat pendidikan dan kualitas kerja karyawan dapat dipercaya. Oleh karena itu angket tingkat pendidikan dan kulitas kerja karyawan dapat digunakan sebagai alat pengumpul data untuk penelitian.

Hasil uji linearitas dapat diketahui bahwa nilai $F_{\text {hitung }}$ sebesar $0,937 \geq F_{\text {tabel }}$ sebesar 4,03 dan nilai Sig linearity sebesar 0,000 $<0,05$. Hal ini berarti bahwa $\mathrm{H}_{a}$ diterima, artinya tingkat pendidikan memiliki pengaruh terhadap kualitas kerja karyawan pada BPR POLATAMA KUSUMA Madiun. Selain itu dapat dikatakan bahwa ada hubungan yang linier antara tingkat pendidikan dan kualitas kerja karyawan. Hasil dari analisis regresi linier sederhana diolah menggunakan program SPSS for windows 16.0 dapat disusun persamaan regresi sebagai berikut.

$$
Y=43,696+0,535 X
$$

Apabila tingkat pendidikan naik sebesar 1\% kualitas kerja karyawan akan naik pula sebanyak 0,535\%, sedangkan faktor lain dianggap tetap. Hasil uji t dapat diketahui bahwa nilai $\mathrm{t}_{\text {hitung }}$ sebesar $0,968 \geq \mathrm{t}_{\text {tabel }}$ sebesar 1,677 pada taraf signifikansi 0,05 . Hal ini berarti bahwa $\mathrm{H}_{\text {a }}$ diterima, artinya tingkat pendidikan memiliki pengaruh terhadap kualitas kerja karyawan pada BPR POLATAMA KUSUMA Madiun.

\section{HASIL PENELITIAN}

Uji instrumen dilakukan di BPR POLATAMA KUSUMA Madiun dengan jumlah 50 responden. Hasil uji menunjukkan bahwa instrumen penelitian dengan angket/kuesioner baik dan bisa digunakan untuk penelitian.
Hasil uji validitas, setelah diuji dengan SPSS dapat dikatakan bahwa semua item dalam angket tingkat pendidikan adalah valid. Hal ini dapat diketahui dari nilai $r_{x y}$ secara keseluruhan hasilnya valid, semua nilai $r_{x y}$ lebih besar $r_{\text {tabel }}\left(r_{x y} \geq r_{\text {tabel }}\right)$. Dari hasil tersebut dapat disimpulkan bahwa semua soal yang ada dalam angket tingkat pendidikan dapat digunakan dalam penelitian. Hasil uji validitas kualitas kerja karyawan setelah diuji dengan SPSS dapat dikatakan bahwa semua item dalam angket kualitas kerja karyawan adalah valid. Hal ini dapat diketahui dari nilai $r_{x y}$ secara keseluruhan hasilnya valid, semua nilai $r_{x y}$ lebih besar $r_{\text {tabel }}\left(r_{x y} \geq r_{\text {tabel }}\right)$. Dari hasil tersebut dapat dikatakan bahwa semua soal yang ada dalam angket kualitas kerja dapat digunakan dalam penelitian.

Setelah uji validitas dilakukan uji reabilitas tingkat pendidikan dan kualitas kerja karyawan diperoleh nilai Cronbach's Alpha masing-masing sebesar 0,873 dan 0,827. Karena nilai Cronbach's Alpha lebih dari 0,7, dapat disimpulkan bahwa data yang dikumpulkan melalui angket tingkat pendidikan dan kualitas kerja karyawan dapat dipercaya. Oleh karena itu angket Tingkat Pendidikan dan kulitas kerja karyawan dapat digunakan sebagai alat pengumpul data untuk penelitian. Hasil uji linearitas dapat diketahui bahwa nilai $\mathrm{F}_{\text {hitung }}$ sebesar $0,937 \geq \mathrm{F}_{\text {tabel }}$ sebesar 4,03 dan nilai Sig linearity sebesar $0,000<0,05$. Hal ini berarti bahwa $\mathrm{H}_{a}$ diterima, artinya tingkat pendidikan memiliki pengaruh terhadap kualitas kerja karyawan pada BPR POLATAMA KUSUMA Madiun.

Analisis regresi linier sederhana digunakan untuk mencari pengaruh antara variabel tingkat pendidikan terhadap variabel kualitas kerja karyawan. Apabila tingkat pendidikan naik sebesar 1\% kualitas kerja karyawan akan naik pula sebanyak $0,535 \%$, sedangkan faktor lain dianggap tetap.

Hasil uji t dapat diketahui bahwa nilai $\mathrm{t}_{\text {hitung }}$ sebesar $0,968 \geq \mathrm{t}_{\text {tabel }}$ sebesar 1,677 pada taraf signifikansi 0,05. Hal ini berarti bahwa $\mathrm{H}_{\mathrm{a}}$ diterima, artinya tingkat pendidikan memiliki pengaruh terhadap kualitas kerja karyawan pada BPR POLATAMA. 


\section{PEMBAHASAN}

\section{Tingkat Pendidikan}

Bahwa tingkat pendidikan SMA memiliki frekuensi dan prosentase yang lebih besar yaitu 34 orang sedangkan S1 13 orang, perawatan 3 orang. Hal ini menunjukkan bahwa responden tingkat pendidikan dari karyawan lebih banyak lulusan SMA. Hal ini dikarenakan PT. BPR POLATAMA KUSUMAlebih banyak membutuhkan karyawan bagian pelayanan sebab usahanya bergerak di bidang layanan. Terdapat 50 responden yang menyumbangkan jawabannya pada kuesioner variabel tingkat pendidikan (X). Tingkat Pendidikan diolah dengan statistik deskriptif menggunakan program SPSS for windows 16.0 yang diperoleh hasil bahwa variabel Tingkat Pendidikan, dengan jumlah n 50 orang dalam statistik deskriptifnya sebagai berikut: (a) Nilai jumlah total skor sebesar 930; (b) Nilai Mean (rata-rata) sebesar 18,60; (c) Nilai median (nilai tengah) sebesar 18,50; (d) Nilai modus (nilai yang sering muncul) sebesar 18; (e) Nilai standar deviasi sebesar 2,523; (f) Nilai minimum sebesar 14; (g) Nilai maximum sebesar 24.

\section{Kualitas Kerja Karyawan}

Dari kuesioner variabel kualitas kerja karyawan dapat diketahui jumlah data kualitas kerja karyawan. Hasil pengjian statistik dapat dikatakan bahwa variabel kualitas kerja karyawan, dengan jumlah N 50 orang dalam statistik deskriptifnya sebagai berikut: (a) Nilai jumlah total skor sebesar 2682; (b) Nilai mean sebesar 53,64; (c) Nilai median sebesar 55,00; (d) Nilai modus sebesar 60; (e) Nilai standar deviasi sebesar 9,752; (f) Nilai manimum sebesar 37; (g) Nilai maximum sebesar 75 .

\section{Pengaruh Tingkat Pendidikan Terhadap Kualitas Kerja Karyawan}

Berdasarkan hasil pengujian hipotesis yang telah dilakukan melalui analisis regresi linier sederhana maka dapat dikatakan bahwa ada pengaruh yang signifikan antara tingkat pendidikan dengan kualitas kerja karyawan. Hal ini dapat terlihat dari hasil persamaan regresi yaitu $Y=43,696+0,535 X$. Artinya apabila tingkat pendidikan naik sebesar 1\% kualitas kerja karyawan akan naik pula sebanyak $0,535 \%$, sedangkan faktor lain dianggap tetap. Dengan demikian hasil hipotesis yang telah dirumuskan dapat diterima kebenarannya.

Pembahasan dalam uji linearitas diperoleh hasil bahwa $\mathrm{F}_{\text {hitung }}$ sebesar 0,937 $\geq \mathrm{F}_{\text {tabel }}$ sebesar 4,03 dan pada taraf signifikansi 0,05. Hal ini berarti bahwa $\mathrm{H}_{\mathrm{a}}$ diterima, artinya tingkat pendidikan memiliki pengaruh terhadap kualitas kerja karyawanpada PT. BPR POLATAMA KUSUMA Madiun. Selain itu dapat dikatakan bahwa ada hubungan yang linier antara tingkat pendidikan dan kualitas kerja karyawan.

Pembahasan dalam uji t diperoleh hasil bahwa nilai $t_{\text {hitung }}$ sebesar $0,968 \geq \mathrm{t}_{\text {tabel }}$ sebesar 1,677 pada taraf signifikansi 0,05 . Hal ini berarti bahwa $\mathrm{H}_{\mathrm{a}}$ diterima, artinya tingkat pendidikan memiliki pengaruh terhadap kualitas kerja karyawan pada BPR POLATAMA KUSUMA.

\section{KESIMPULAN DAN SARAN}

\section{Kesimpulan}

1. Tingkat pendidikan memiliki nilai rata-rata sebesar 18,60 dengan nilai maksimum 24, nilai minimum 14 , standar deviasi 2,523, median 18,50 dan modus sebesar 18. Dari hasil deskripsi variabel tingkat pendidikan diketahui bahwa responden cenderung setuju terhadap tingkat pendidikan yang digunakan manajer (rata-rata 18,60), artinya bahwa pada umumnya responden setuju jika manajer dalam memberikan tugas ada penjelasannya, cara mengerjakannya dan intruksinya jelas.

2. Kualitas kerja karyawan memiliki nilai ratarata sebesar 53,64 dengan nilai maksimum 75 , nilai minimum 37 , standar deviasi 9,752, median 55,00 dan modus sebesar 60 . Dari hasil deskripsi variabel kualitas kerja karyawan diketahui bahwa responden cen- 
derung mempunyai kualitas kerja (rata-rata 53,64), artinya bahwa pada umumnya responden terkualitas karena alasan kebutuhan ekonomi, karena ingin mendapatkan kesempatan berkembang dan karena ingin diakui dirinya sebagai seorang manusia.

3. Dalam hasil analisis regresi diperoleh persamaan $\mathrm{Y}=43,696+0,535 \mathrm{X}$ yang menunjukkan bahwa salah satu faktor yang mempengaruhi kualitas kerja karyawan adalah tingkat pendidikannya. Selain itu, juga diperoleh nilai $\mathrm{t}_{\text {hitung }}$ sebesar $0,968 \geq \mathrm{t}_{\text {tabel }}$ sebesar 1,677 berarti $\mathrm{H}_{\mathrm{a}}$ diterima dan $\mathrm{H}_{0}$ ditolak artinya ada pengaruh antara tingkat pendidikan dengan kualitas kerja karyawan pada PT. BPR POLATAMA KU-SUMA Kota Madiun. Apabila tingkat pendidikan naik sebesar 1\% kualitas kerja karyawan akan naik pula sebanyak 0,535\% sedangkan faktor lain dianggap tetap.

\section{Saran}

1. Bagi BPR POLATAMA KUSUMA Kab. Madiun

Perusahaan perlu memperhatikan dan menerapkan tingkat pendidikan transaksional karena telah terbukti dapat secara efektif meningkatkan kualitas kerja karyawan. Kualitas kerja karyawan tinggi jika karyawan mendapatkan insentif atau bonus dari atasan, bonus atau insentif akan diberikan jika ada karyawan yang bisa membawa konsumen untuk menikmati jasa yang ditawarkan pada BPR POLATAMA KUSUMA.

2. Bagi Karyawan BPR POLATAMA KUSUMA

Hendaknya karyawan mampu beradaptasi atau menyesuaikan tingkat pendidikan yang digunakan atasan sehingga karyawan akan terkualitas dalam bekerja.

\section{DAFTAR PUSTAKA}

Andre E. Sikula. 2003. Pengaruh Tingkat Pendidikan Terhadap Produktifitas Kerja Karyawan Bagian Produksi Pada Maharani Handicraft di Kab. Bantul. Skripsi Tidak Diterbitkan. Yogyakarta: Fakultas Ekonomi Universitas Negeri Yogyakarta.

Dorothea Wahyu Ariani. 2003. Manejemen Kualitas Pendekatan Sisi Kualitatif. Jakarta: Ghalia Indonesia.

Gabriel Amin Silalahi. 2003. Metodologi Penelitian Dan Studi Kasus.Sidoarjo: Citra Media.

Juwita Sari. 1995. Analisis Pengembangan Dalam Meningkatkan Kualitas Kerja Pada PT. Bank Muamalat Tbk Cabang Medan. Skripsi Tidak Diterbitkan. Medan: Fakultas Ekonomi Universitas Sumatra Utara Medan.

Juwita Sari. 2001. Analisis Pengembangan Dalam Meningkatkan Kualitas Kerja Pada PT. Bank Muamalat Tbk Cabang Medan. Skripsi Tidak Diterbitkan. Medan: Fakultas Ekonomi Universitas Sumatra Utara Medan.

Tutik, Hartini. 2002. Pengaruh Tingkat pendidikan Dan Pemberian Insentif Terhadap Kinerja Karyawan Pada PT. Garuda Plasa Hotel Medan. Skripsi Ini Tidak Diterbitkan. Medan: Fakultas Ekonomi Universitas Sumatra Utara Medan.

Tutik, Hartini. 2003. Pengaruh Tingkat pendidikan Dan Pemberian Insentif Terhadap Kinerja Karyawan Pada PT. Garuda Plasa Hotel Medan. Skripsi Ini Tidak Diterbitkan. Medan: Fakultas Ekonomi Universitas Sumatra Utara Medan. 